\title{
URBAN RESILIENCE DEFINITIONS AND LIMITS OF CONCEPTUAL INTERPRETATION
}

\author{
Liviu Bogdan VLAD * \\ Bucharest Academy of Economic Studies, e-mail: liviubogdanvlad@yahoo.com
}

Citation: Vlad, L.B. (2020). Urban Resilience Definitions and Limits of Conceptual Interpretation. Revista Română de Geografie Politică, 22(2), 84-89. https://doi.org/10.30892/rrgp.222104-337

\begin{abstract}
Urban resilience is the capacity of cities to confront any potential and actual challenges through anticipation, adaptation and recovery. There are many definitions of urban resilience, each focusing on a different aspect - government, administration, society, economy, capacity to withstand outside and/or inside threats, ability to grow and so on. When analyzed and taken as a whole, our view is that these theories create the image of the city as a living organism, made up of a number of elements that must work together in order to maintain it resilient to shocks and capable of absorbing shocks. The fundamental unit of this organism is the individual - and the individual's resilience gives the tone for the resilience of the whole. From this perspective, we can say that urban resilience works like an immune system - its role is mainly to prevent but, when needed, also to withstand actively against any threats and/or shocks.
\end{abstract}

Key words: resilio, economic shocks, political shocks, social shocks, durable development, climate changes, systemic characteristics of resilience, development of human communities

* * * * *

\section{INTRODUCTION}

The capacity to withstand shocks - resilience - comes from the Latin word resilio, "to leap or spring back, to recoil, to rebound” (Muller, 2010, p. 1).

It means the ability to withstand - through anticipation, adaptation and recovery - any potential difficulties, crises, pressures, challenges, losses, abuses, failures, poverty, abandonment, personal or natural catastrophes, unfavourable stimuli etc. Psychology borrowed the term from the resistance of materials, which can be "folded and bent without breaking, only to come back to their initial shape" (Collin, 2002). 


\section{METHODOLOGY}

In order to better understand what resilience in general - and urban resilience in particular - means, let us first look at some of the most important types of shocks: economic and financial (recession, inflation, lack of resources, poverty etc.), political (dictatorship, war, terrorist threats etc.), ecological (natural catastrophes, epidemics, global warming, severe effects of pollution etc.), informational (informational attacks, media disinformation, manipulation), scientific (rapid change of technologies), criminal (mafia, corruption). Institutional resilience (economic, geopolitical) is the capacity of geopolitical and economic institutions to withstand shocks that threaten internal structures, driven by the power to react and communicate interpersonally that should be a feature of their members and of everyone responsible for their effective operation.

In psychology and in other social sciences, the term means the ability to go through disturbing, stressful and risky situations without being irreversibly affected by them. It is, therefore, the ability to react and respond to something that takes us out of a state of equilibrium and to recover by integrating that something in a superior balance. It has been said it has a compensatory, protective or adversative function. The term has been used with several meanings : "a good development in spite of social danger, retaining competences in spite of continuous stress and recovering after a trauma" (Werner, 1995, p. 81); "the process of adapting well in the face of adversity, trauma, tragedy, threats, or significant sources of stress-such as family and relationship problems, serious health problems, or workplace and financial stressors. As much as resilience involves bouncing back from these difficult experiences, it can also involve profound personal growth" (American Psychological Association, 2012); "resistance relative to the psychosocial stress" (Rutter, 1999, p. 119); „refers to a dynamic process encompassing positive adaptation within the context of significant adversity; [...] exposure to significant threat or severe adversity; and the achievement of positive adaptation despite major assaults on the developmental process" (Luthar et al., 2000, p. 543).

However, it is not merely an individual capacity, but one to which many contextual factors contribute. A living organism might be the most suggestive example, since all its parts collaborate with the environment through constant changes, on different levels, in order to maintain its dynamic balance, in spite of factors that threaten its health. Let us use this analogy going forward.

Urban resilience is, therefore, the capacity of the city as an organismic unit to absorb shocks: demographical (overcrowding, depopulation), informational (cyber-attacks), media (fake news, panic attacks), financial (sudden variations of the financial market, financial blocks, payment defaults), industrial (pollution, risk of explosions), administrative (bureaucratization), economic (decrease in the standard of living, unemployment rate, lack of social protection, strikes), political (corruption, crises), communicational (improper infrastructure), juridical (inability to protect the citizens' rights and liberties, abuses), natural (earthquakes, floods), alimentary (selling of rotten or out of date food), criminal (terrorism, areas with a high risk of criminality), psychological (attacks by mentally disturbed persons), religious (dangerous religious sects), cultural and sportive (inability to sponsor or finance, subculture), educational (illiteracy), health (improper sanitation), energetic (power outages, gas outages), ecologic (pollution or buildings that suffocate the 
green environment) etc. Lack of communication between structures of public administration and between these structures and the private environment is another aspect that weakens urban resilience.

Urban resilience has also been defined as:

- "the ability of persons, communities, institutions, businesses and systems inside a city to survive, adapt and grow, in spite of any chronic tensions and acute shocks they might experiment" (Silva, 2012, p. 3).

- "the process of urbanization and planning through healthy development practices, inclusive political processes, reducing the risk of disasters through the actions of the government, the citizens or any other parts involved" (Johnson and Blackburn, 2012, p. 11).

- "A resilient city is a sustainable network of physical systems and human communities" (Godschalk, 2003, p. 137).

- "Resilient cities reduce vulnerability to extreme environments and respond creatively to economic, social and environmental changes in order to increase long-term sustainability" 1 .

- "A resilient city is characterized by its ability to resist or absorb the impact of a risk or danger through resistance and adaptation, which allow it to maintain certain functions and fundamental structures during a crisis and to recover after such an event" (Twigg, 2007 cited in Johnson and Blackburn, p. 6).

- "a city's ability to react to terror and crises without losing what makes it attractive, livable and interesting". ${ }^{2}$

- "what helps cities adapt and transform in the face of challenges in order to prepare for the expected and the unexpected". ${ }^{3}$

- "Traditionally, OECD tends to use resilience as meaning the capacity to withstand crises. We acknowledge that the systemic threats against modern societies are increasingly difficult to put into a model and are often too complex to be solved by using the traditional approaches to risk estimation that focus first on the rigidity of the system and its ability to absorb threats before the break. The new approach to resilience will focus on the system's ability to anticipate and absorb, to recover and adapt to a large spectrum of systemic threats" (Linkov et al., p.134).

- "A resilient city or a resilient society has a greater capacity to adapt and is capable of adapting to the changing environmental or contextual conditions and to quickly recover from the negative consequences. Resilience can therefore be understood as a comprehensive, holistic approach to the problem, with the purpose to maintain the general capacity of resisting, regenerating and developing of natural and social systems. Under the circumstances of the city's transformation, resilience is oriented towards the future and faces the challenge to recognize and anticipate the dynamics of development early on. This evolutionary model of adaptive cycles is based on two factors: on the one hand, the resources specific to the systems ("the structural potential" for a change) and on the other the degree of connectivity ("internal connectivity"), which is the degree of internal association of various elements in a system, which can, for example, be increased by creating networks in the social context" (Fekkak, 2016, p. 10-11).

\footnotetext{
${ }^{1}$ https://sustainabledevelopment.un.org/partnership/?p=1622

${ }^{2}$ https://www.transforming-cities.de/urbane-resilienz-schutz-des-oeffentlichen-raums/

${ }^{3}$ www.100resilientcities.org
} 


\section{RESULTS AND DISCUSSION}

Prof. Ulf Hahne identifies four characteristics of resilience: robustness, response time, redundancy (reserves and resources), learning capacity (Prof. Dr. Ulf Hahne, Resilienz, Raum und Steuerung). We find that "planning a resilient city requires using dichotomic concepts: redundancy and efficiency, diversity and interdependence, stability and flexibility, autonomy and cohesion, control and unpredictability" (Ann-Kristin Winkens, Die Grenzen der Stadt - Urbane Resilienz).

An essential factor for improving resilience is the specific interconnectivity of living organisms. "Humboldt was a firm believer that the distinct disciplines were artificial divisions of knowledge and that the key to understanding nature was interconnectivity. He wrote in his journal: Everything is interconnected and interdependent" (Doherr, 2015, p. 47).

Furthermore, Humboldt observes, "the main impulse that guided me was the serious effort to understand the phenomena of physical objects in their general connection and to represent nature as a great totum moved and animated by internal forces" (Schrodt et al., 2019, p. 1636).

In the concept of urban resilience are mingled two factors: the force or the activity of the social organism and its passive resistance. According to Leibniz, "without a doubt, entelechia - that is, the force or the activity - is different from resistance or passivity in that the former can be seen as form and the latter as raw matter; however, they are not so different that they must be viewed as two different substances, but as parts of one unique substance, and the force that moves the raw matter is, in any case, not the force of the raw matter, but entelechia itself. (...) Should one leave out entelechia, one cannot find true unity" (Leibniz, 1872, p. 382-383).

Given that the increase in social contrasts leads to a decrease in resilience, we consider the difference between the medium wage and the minimum wage as a relevant indicator of economic resilience.

One other indicator of economic resilience, beyond the inflation rate and the unemployment rate, is the difference in numbers between the young population and the old population, with the decrease in birth rate being directly proportional to the decrease in resilience.

Resilience is improved through the social assistance of private firms, donors and volunteers, with the involvement of the state.

As is the case with a living organism, where when certain structures fail, others can take over their function, resilience is the urban, economic, social etc. organism's ability to take over as a whole the functions of certain structures affected by shocks. This can happen on the one hand through the spontaneous regulative dynamism of the local community and of the state, and on the other through a continuous effort of anticipating possible shocks by tempering their impact or even avoiding them altogether through searching and finding solutions in advance.

It is important for the institutions able to anticipate urban shocks to not be commanded by political or economic interests which can generate false predictions, in turn deepening the state of shock.

Religious thought can be a catalyst for the ability to resist when it becomes that point of support in transcendence which avoids panic and dramatically influences resilience. Furthermore, a religious thought that surpasses the logic of fighting and antagonism, of self-affirmation against alterity, and embraces o 
logic of communion with a cosmic extension by asserting the dignity of the iconic figure of man and creation helps improve resilience as a factor regulating the conflict that undermines social, economic, urban etc. "immunity".

An important element of resilience is the relationship between law and freedom, which must be moderated so that it stimulates and gives room for personal initiative that might generate order for the benefit of the community, but also limits and disarms the individual's destructive actions.

The work of the virtues that make the human consciousness transparent and open to the loving interplay with other consciousness is essential, because inter-subjectivity - that is, communication between consciousnesses - is the unquantifiable foundation of resilience, both in a passive and an active sense. The actuality and the implementation on a social level of this work of the virtues is difficult given the diversity of individual options, but a communication based on the logic of dialogue, integrating local specificities and diversities, is crucial. The rigidity or lack of flexibility found in planning and governing policies (in the case of dictatorships, for example) or in defense, adaptation and innovation systems is a major risk for the collapse of resilience.

Since any form of resilience is based on personal resilience, the education system, the professional and academic systems and the medical system are keyelements that stimulate resilience, through support and investments. Infrastructure, telecommunications, mass-media are also factors that increase inter-subjectivity and bring essential value to the field of resilience.

Last but not least, man's relationship with nature, his vital environment, is a key-element in the equation of resilience. Man's mindfulness towards the health and environmental balance of the planet is today more important than ever, as the effects of pollution and global warming accumulate and start irreversible phenomena on a global level.

\section{CONCLUSION}

Resilience is, in some sense, the equivalent of an immune system that helps the organism prevent potential external and internal attacks, diseases and shocks that - once the organism has been weakened - turn from potential threats to actual threats.

\section{Aknowlegments}

This work was supported by a grant of Ministry of Research and Innovation CNCS - UEFISCDI, project number PN-III-P4-ID-PCCF-2016-0166, within the PNCDI III project "ReGrowEU - Advancing ground-breaking research in regional growth and development theories, through a resilience approach: towards a convergent, balanced and sustainable European Union".

\section{REFERENCES}

American Psychological Association (2012), retrieved from https://www.apa.org/topics/resilience. (Accessed at 22 Septembrie 2020).

Collin, Dominique (2002) Brouillard ou arc-en-ciel de sens. Retrieved from http:/ /lionel.mesnard.free.fr/le\%20site/psy-resilience.html (Accessed at 22 Septembrie 2020).

Doherr, D. (2015). Alexander von Humboldt's idea of interconnectedness and its relationship to interdisciplinarity and communication. The Journal on Systemics, Cybernetics and Informatics (JSCI), 13(6), 47-51. 
Fekkak, M., Fleischhauer, M., Greiving, S., Lucas, R., Schinkel, J., \& von Winterfeld, U. (2016). Resiliente Stadt-Zukunftsstadt. Forschungsgutachten im Auftrag des Ministeriums für Bauen, Wohnen, Stadtentwicklung und Verkehr des Landes Nordrhein-Westfalen. Düsseldorf.

Godschalk, D. R. (2003). Urban hazard mitigation: creating resilient cities. Natural hazards review, 4(3), 136-143.

Johnson, C., \& Blackburn, S. (2012). Making Cities Resilient Report 2012. My city is getting ready! A global snapshot of how local governments reduce disaster risk.

Leibniz, G.W. (1972). Opere filosofice, vol. I, Editura Științifică și Enciclopedică, 382-383, 393.

Linkov, I., Trump, B. D., Poinsatte-Jones, K., Love, P., Hynes, W., \& Ramos, G. (2018). Resilience at OECD: current state and future directions. IEEE Engineering Management Review, 46(4), 128135. Retrieved from : https://www.oecd.org/naec/projects/resilience/Resilience_OECD.pdf (Accessed at 22 Septembrie 2020)

Luthar, S. S., Cicchetti, D., \& Becker, B. (2000). The construct of resilience: A critical evaluation and guidelines for future work. Child development, 71(3), 543-562. Retrieved from https://www.ncbi.nlm.nih.gov/pmc/articles/PMC1885202/ (Accessed at 20 Septembrie 2020).

Muller, B. (2010). Urban and Regional Resilience - A New Catchword or a Consistent Concept for Research and Practice? In. German Annual of Spatial Research and Policy 2010, 1-13.

Rutter, M. (1999). Resilience concepts and findings: Implications for family therapy. Journal of family therapy, 21(2), 119-144.

Schrodt F., Santos, M. J., Bailey J.J., Field, R.( 2019). Challenges and Opportunities for Biogeography What Can We Still Learn from von Humboldt ?, 1631-1642. Retrieved from : https://onlinelibrary.wiley.com/doi/epdf/10.1111/jbi.13616 (Accessed at 20 Septembrie 2020).

Silva, J. D., \& Morera, B. (2014). City resilience framework. City Resilience Index, The Rockefeller Foundation and ARUP, London.

Twigg, J. (2007). Characteristics of a disaster-resilient community: A guidance note, London: DFID DRR Interagency Coordination Group. Retrieved http:/ / lib.riskreductionafrica.org/bitstream/handle/123456789/623/characteristics\%20of\% 20a.pdf?sequence=1. (Accessed at : 24 Septembrie 2020).

Werner, E. E. (1995). Resilience in development. Current directions in psychological science, 4(3), 81-84.

\section{Websites:}

http://philou.rwth-aachen.de/?p=1873, Winkens, A.-K., Die Grenzen der Stadt - Urbane Resilienz, (Accessed at: 11 Decembrie 2019).

www.100resilientcities.org, Programul 100 Resilient Cities, (Accessed at: 11 Decembrie 2019).

https://sustainabledevelopment.un.org/partnership/?p=1622, (Accessed at : 24 Septembrie 2020)

Submitted:

March 21, 2020
Revised:

June 20, 2020
Accepted and published online:

November 03, 2020 